\title{
Production and initial growth of forest species seedlings using sewage sludge and automated irrigation
}

\section{Produção e crescimento inicial de mudas de espécies arbóreas utilizando lodo de esgoto e irrigação automatizada}

\author{
Daniel Fonseca de Carvalho ${ }^{1 *}\left(\mathbb{D}\right.$, Mateus Marques Bueno ${ }^{2} \mathbb{D}$, Paulo Sérgio dos Santos Leles ${ }^{3}$,

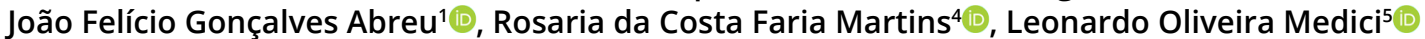

\author{
'Universidade Federal Rural do Rio de Janeiro/UFRRJ, Departamento de Engenharia, Seropédica, RJ, Brasil \\ ${ }^{2}$ Instituto Federal de Educação, Ciência e Tecnologia de Minas Gerais/IFMG, São João Evangelista, MG, Brasil \\ ${ }_{3}^{3}$ Universidade Federal Rural do Rio de Janeiro/UFRRJ, Departamento de Silvicultura, Seropédica, RJ, Brasil \\ ${ }^{4}$ Universidade Federal Rural do Rio de Janeiro/UFRRJ, Instituto de Fitotecnia, Seropédica, RJ, Brasil \\ ${ }^{5}$ Universidade Federal Rural do Rio de Janeiro/UFRRJ, Instituto de Agronomia, Seropédica, RJ, Brasi \\ ${ }^{*}$ Corresponding author: daniel.fonseca.carvalho@gmail.com \\ Received in August 10, 2021 and approved in October 19, 2021
}

\begin{abstract}
Traditionally, irrigation management has not been used in forest nurseries, compromising the efficiency of the system and the quality of seedlings. In this study, we evaluated the quality of seedlings under different irrigation levels and the substrate composed of pure biosolid, and the initial growth of three Atlantic Forest tree species, produced with automated irrigation management. Four irrigation levels (V1 to V4) were applied by dripping on Schizolobium parahyba (Vell.) Blake, Cytharexyllum myrianthum Chamiáo and Ceiba speciosa Ravenna seedlings. After that, the seedlings were planted to evaluate their early growth in pots. The water was applied in response to species requirement and the volume was measured by water flow sensors, connected to an Arduino MEGA board. Height, collar diameter, leaf area, dry mass and chlorophyll content measurements were used to assess plant development on the seedling and early growth stages. Seedlings that received the highest average volume of water (V4) had a higher rate of growth in height and collar diameter for the three species studied. Despite this, the seedlings that received a smaller volume of water (V1) achieve similar size than V4 ones in pots. The plant growth and quality data, in the two phases analyzed, together with the aggregation of the substrate, indicate that the ideal irrigation level is linked to treatments that received the highest volumes of water (V3 and V4) in the seedling production phase. The results obtained indicate that it is possible to save water and produce seedlings of forest species with quality, ensuring their survival in the field.
\end{abstract}

Index terms: Water limitation; substrate; chlorophyll index.

\begin{abstract}
RESUMO
Tradicionalmente, viveiros florestais não utilizam manejo da irrigação, comprometendo a eficiência do sistema e a qualidade das mudas. O objetivo desse estudo foi avaliar a qualidade de mudas sob diferentes níveis de irrigação e do substrato composto por biossólido puro, e o crescimento inicial de três espécies arbóreas de Mata Atlântica, produzidas com manejo automático da irrigação. Quatro níveis de irrigação (V1 a V4) foram aplicados por gotejamento em mudas de Schizolobium parahyba (Vell.) Blake, Cytharexyllum myrianthum Chamiáo e Ceiba speciosa Ravenna. Em seguida, as mudas foram plantadas para avaliar seu crescimento inicial em vasos. A água foi aplicada em resposta à necessidade das espécies e os volumes foram medidos por sensores de fluxo de água, conectados a uma placa Arduino MEGA. Medidas de altura, diâmetro do colo, área foliar, massa seca e teor de clorofila foram utilizadas para avaliar o desenvolvimento das plantas na fase de mudas e nos estágios iniciais de crescimento. Mudas que receberam o maior volume médio de água (V4) tiveram maior taxa de crescimento em altura e diâmetro do colo para as três espécies estudadas. Apesar disso, as mudas que receberam menor volume de água (V1) atingem tamanhos semelhantes às do tratamento V4 em vasos. Os dados de crescimento e qualidade das plantas, nas duas fases analisadas, juntamente com a agregação do substrato, indicam que o nível ideal de irrigação está vinculado aos tratamentos que receberam os maiores volumes de água (V3 e V4) na fase de produção de mudas. Os resultados obtidos indicam que é possível economizar água e produzir mudas de espécies florestais com qualidade, garantindo sua sobrevivência no campo.
\end{abstract}

Termos para indexação: Limitação hídrica; substrato; índice de clorofila. 


\section{INTRODUCTION}

The global concern for environmental quality is increasingly frequent and has led to an increase in the demand for forest services and products (Laakkonen et al., 2018), especially in the production of seedlings of tree species. In this sense, the quality of seedlings is an important factor, because they must develop and withstand the adversities that can affect them in the field (Silva et al., 2020).

Seedling growth is dependent on the climatic characteristics of the production environment (Alves Junior et al., 2017), which can be carried out in nurseries or in controlled places such as greenhouses. In addition, the availability of water (Keffer et al., 2019) and the substrate used (Sabonaro; Galbiatti, 2007), interfere in the growth and quality of the seedlings. The water content is indicative of its availability in the substrate and its control is important for sustainable irrigation practice and reduction in the negative impact on the environment (Boluwade; Madramootoo, 2016). Water management in response to the crop water requirements can be done automatically, contributing to the maximization crop yield. The simplified irrigation controller (SIC) proposed by Medici et al. (2010), which operates in response to soil water tension, has been successful used in several environments (Gomes et al., 2017; Mello et al., 2018; Bueno et al., 2021; Cruz et al., 2022) and it stands out for being low cost and easy to operate (Valença et al., 2018).

Water limitations can interfere in the growth dynamics of both the root system and the shoots, since more severe droughts can reduce the plant's ability to convert chemical energy into biomass (Mantri et al., 2012). Morphological changes in growth are also likely to occur in situations of either lack or excess of water (Anjum et al., 2011), but the responses of plants are complex and involve adaptive changes (Oliveira et al., 2013), varying for each species. This aspect is especially important in nurseries, where about 49 to $72 \%$ of the total applied is lost (Dumroese et al., 2005).

The quality of the seedling is also associated with the substrate used in the production process. In addition to improving the quality of degraded soils, based on increased organic matter and aggregate stability (Zoghlami et al., 2020), sewage sludge, called biosolid after treatment and stabilization, has been employed in the production of forest seedlings and its use is promising for containing high levels of organic matter and nutrients, in addition to improving water retention (Siqueira et al., 2019) and promoting good aeration for root development (Lima Filho et al., 2019). Its use in agriculture reduces the pressure on landfills, bringing more sustainability to sanitation and to the forestry sector.

The variables used for the selection of seedlings at the time of planting are based on either phenotypic aspect, called morphological, or internal aspects of seedlings, called physiological (Gomes et al., 2002). Morphological aspects are more intuitive and are generally more used. However, a more careful quality analysis should involve other variables, such as biomass accumulation, leaf area and chlorophyll content. Another important factor in the quality of seedlings is the time of permanence in the nursery, because the faster the seedling is produced, the greater the space optimization and the lower the cost of production (Souza et al., 2003).

The objective of this study was to evaluate the quality of seedlings under different irrigation levels and the substrate composed of pure biosolid, and the initial growth of three Atlantic Forest tree species, produced with automated irrigation management.

\section{MATERIAL AND METHODS}

The experiments were conducted from September 2018 to May 2019, in the municipality of Seropédica - RJ, Brazil, and consisted of the production of seedlings (Phase I) and initial growth (Phase II) of three tree species of the Atlantic Forest: Schizolobium parahyba (Vell.) Blake 'Guapuruvu', Cytharexyllum myrianthum Chamiáo - 'Pauviola' and Ceiba speciosa Ravenna - 'Paineira'.

The seedlings were produced in an air-conditioned environment, while the growth phase occurred in a traditional greenhouse. In both experiments, meteorological monitoring was performed by a weather station (WatchDog, model: 2900ET), containing sensors of temperature, relative humidity, solar radiation and wind speed, and with data stored every 30 minutes.

\section{Production of seedlings (Phase I)}

The phase of seedling production (Phase I) lasted 80 days, from September 4 to November 24, 2018. In this period, the temperature in the air-conditioned greenhouse ranged from 21.3 to $32.1{ }^{\circ} \mathrm{C}$, with the maximum daily average of $27.0{ }^{\circ} \mathrm{C}$ in October. The average relative humidity in the same period was $81 \%$. The seeds used were collected from mother trees from the Atlantic Forest of the State of Rio de Janeiro and the sowing took place directly in $280 \mathrm{~cm}^{3}$ tubes.

The experiments were conducted in a completely randomized design, with 4 treatments (irrigation levels, V1 
to V4) and 15 replicates, totaling 60 seedlings per species. Irrigation management was carried out by means of the simplified irrigation controller (SIC) (Medici et al., 2010), with a $40 \mathrm{~cm}$ distance between the sensor and the pressure switch, indicating an actuation tension of approximately $4.0 \mathrm{kPa}$. The emitters used were of spaghetti microtube type (Plasnova, mod. PDAEXT001000354), with 0.8 $\mathrm{mm}$ in diameter and different lengths $(80,50,35$ and 20 $\mathrm{cm}$ ), which operated at $16.7 \mathrm{kPa}$, promoting flow rates of $1.2,1.8,2.1$ and $2.9 \mathrm{~L} \mathrm{~h}^{-1}$ (S. parahyba), 1.1, 1.5, 2.3 and $2.6 \mathrm{~L} \mathrm{~h}^{-1}$ (C. myrianthum) and $0.7,1.1,1.4$ and $1.8 \mathrm{~L} \mathrm{~h}^{-1}$ (C. speciosa), respectively, for V1, V2, V3 and V4. The distribution uniformity coefficients (DUC) calculated for each experimental bench were higher than $95 \%$. The SIC sensor was installed in the substrates of two seedlings, for each species, which were subjected to the treatment of highest flow rate (V4).

The volume of water applied per treatment was measured by water flow sensors (mod. YF-S201b), connected to an Arduino MEGA board (mod. 2560). In order to avoid possible losses by percolation, a rain sensor was installed (mod. HDCL) below two tubes per species that received higher flow rate (V4). The system was actuated directly via relay, which interrupted irrigation if necessary.

The substrate used was only biosolid, obtained from a sewage treatment plant (STP) managed by the Rio de Janeiro State Water and Sewage Company - CEDAE. According to Abreu et al. (2017), the greater the proportion of biosolids in the substrate, the greater the nutrient content, especially $\mathrm{N}, \mathrm{P}$ and $\mathrm{K}$, and the greater its water retention capacity.

The physical and chemical characteristics of the substrate were obtained according to methodologies presented by Fermino (2014) and Teixeira et al. (2017), respectively, immediately before and at the end of the first experimental phase. Data was compared and analysis of variance was performed. For this, the normality and homogeneity of the residuals were checked by the ShapiroWilk and Bartlett tests, respectively, at 5\% probability level. For volumetric density (Dv), particle density (Dp) and porosity $(\mathrm{P})$, Tukey test was applied to compare the mean values of the treatments (V1 to V4) and the Dunnett test to compare the mean values of $\mathrm{V} 0$ in relation to each treatment.

The water retention curve (Equation 1), according to the model proposed by Van Genuchten, was obtained by the simplified evaporation method (Schindler; Miller, 2006), operationalized by commercial device Hyprop ${ }^{\circledR}$ (Pertassek; Peters; Durner, 2015). The substrate showed density of $0.41 \mathrm{~g} \mathrm{~cm}^{-1}$ and the water retention at $10 \mathrm{kPa}$ was equal to $0.30 \mathrm{~cm} \mathrm{~cm}^{-3}$, corresponding to the field capacity.

$$
\theta=4.3^{-6}+\frac{0.72}{\left[1+(0.27 * h)^{1.24}\right]^{0.44}}
$$

where $\theta$ is the substrate moisture $\left(\mathrm{cm} \mathrm{cm}^{-3}\right)$ and $\mathrm{h}$ is the matric potential $(\mathrm{kPa})$.

Every 15 days, measurements of plant height, collar diameter and chlorophyll content (Clorofilog, Model CFL1030) were taken, in a total of 5. Chlorophyll reading was always performed in the second fully developed leaf of the seedlings in the different treatments. At the end, part of the seedlings (4 per treatment) were used to characterize leaf area and biomass. To this end, all leaves of these seedlings were removed for the measurement of leaf area, with a leaf area meter (mod. LI-3100C). Shoot dry mass (SDM) and root system dry mass (RDM) were also determined. These data, together with those of height and diameter, were used to calculate the Dickson quality index - DQI (Dickson et al., 1960).

With the results of the fortnightly and final measurements, the analysis of variance was performed and, for this, the normality and homogeneity of the residues were verified by the Shapiro-Wilk and Bartlett tests, respectively, at $5 \%$ probability. When significant, using the $\mathrm{F}$ test at 5\% probability level, regression analysis was performed by Student's t-test to verify the fit of linear and quadratic models to the biometric data in response to the irrigation levels. For the selection of the model, the one with the lowest significance level ( $p$-value) and the highest coefficient of determination was considered.

For the cases in which the same regression model was selected, depending on the treatments, the identity test of Graybill (2000) was applied at 5\% probability level, using the F test. All analyses were performed with the computer programs R (3.6.0) and Sisvar (5.6).

After the last measurement, for the rest of the seedlings, the plants were classified as to substrate aggregation and presence of living roots, according to the methodology adapted by Moreira et al. (2016). When the seedlings were removed from the tubes, grades were assigned by the same evaluator, according to: ease to remove the seedling from the tube; presence of living roots along the substrate; and type of aggregation (do not crumble, crumbles a little and crumbles easily). The final classification adopted was excellent (A), good (B) or poor (C). After this classification, these seedlings were planted in pots, simulating the conditions of field planting. 


\section{Simulation of initial growth (Phase II)}

Phase II occurred from November 24, 2018, to April 23, 2019, and was characterized by the planting of 16 seedlings of each species ( 4 of each previous treatment), from Phase I. For Phase II, the treatments were called PV1 to PV4, for each species. The experiment was conducted in a plastic greenhouse, simulating the field conditions, except for the water supply, performed by irrigation. In this period, the maximum and minimum daily averages of air temperature and relative humidity ranged from 21.2 to $37.3{ }^{\circ} \mathrm{C}$ and from 45.2 to $90.8 \%$.

The seedlings were planted in conical pots with a volumetric capacity of 18 liters, lower diameter of $25 \mathrm{~cm}$, upper diameter of $30 \mathrm{~cm}$ and height of $28 \mathrm{~cm}$, simulating average dimensions of the planting holes. The substrate used was composed of soil material collected from the 0-40 cm layer of a Neossolo Quartzarênico (Entisol), originating from an area located in the municipality of Seropédica/RJ. This soil had A horizon with about $20 \mathrm{~cm}$ depth, followed by $\mathrm{C}$ horizon up to $120 \mathrm{~cm}$. The dominant particle-size fraction is sand and loamy sandy, with average $\mathrm{pH}$ of 5.2 and base saturation (V) in the A horizon of $36 \%$, indicating relatively low fertility.

In this phase, the same level of irrigation was applied to the three species. Thus, the name of the treatments changed to plants of treatment V1 to V4 (PV1 to PV4), indicating that the plants evaluated in this phase come from the seedlings that received different volumes of irrigation in the seedling production phase (Phase I).

Three independent irrigation systems (one for each species), with management by SIC, were installed. For each system, two sensors were installed in the substrates (soil) in PV4 plants, $15 \mathrm{~cm}$ from the pot surface, maintaining the actuation tension of $4.0 \mathrm{kPa}$. The irrigation system was composed of one dripper per pot (mod. PCJ Netafim), with nominal flow rate of $1.2 \mathrm{~L} \mathrm{~h}^{-1}$ at a pressure of $19.6 \mathrm{kPa}$. The volume of water applied was measured every day, by means of readings in water meters (Alpha $\mathrm{mnf} / \mathrm{FAE}$ ) installed in the main line, previously calibrated. Uniformity tests indicated DUC above $97.0 \%$.

In this phase, measurements of plant height and collar diameter were taken every 30 days, totaling 6 measurements. At 150 days after planting (DAP) of the seedlings in the pots, all 48 plants were used to measure the leaf area and obtain shoot dry mass (SDM) and root system dry mass (RDM).

Analysis of variance was performed and, for this, the normality and homogeneity of the residuals were checked by the Shapiro-Wilk and Bartlett tests, respectively, at $5 \%$ probability level. When significant, using the $\mathrm{F}$ test at $5 \%$ probability level, regression analysis was performed by Student's t-test to verify the fit of the linear and quadratic models to the biometric data, in response to the seedlings produced with different irrigation levels. For the selection of the model, the one with the lowest significance level ( $p$-value) and highest coefficient of determination was considered.

For the cases in which the same regression model was selected, depending on the treatments, the identity test of Graybill (2000) was applied at 5\% probability level, using the $\mathrm{F}$ test. When the models were considered identical, a single equation was generated to represent them. All analyses were performed with the aid of the computer programs R (3.6.0) and Sisvar (5.6).

\section{RESULTS AND DISCUSSION}

\section{Production of seedlings (Phase I)}

The total water consumption and the number of actuations of the irrigation system varied among the tree species studied in the seedling production phase (Table 1). The differences in volume applied between the species occur due to the physiological and growth characteristics of the plants, since they were all exposed to the same environmental conditions. The number of actuations and average volume applied (1.56 L per plant) were higher for Schizolobium parahyba, in response to the greater plant growth.

Table 1: Actuation of the irrigation system and total irrigated volume for the experimental periods, per treatment (V1 to V4), for three tree forest species.

\begin{tabular}{lccccc}
\hline \multirow{2}{*}{ Species } & \multirow{2}{*}{$\begin{array}{c}\text { Number of } \\
\text { irrigations }\end{array}$} & \multicolumn{4}{c}{$\begin{array}{c}\text { Irrigated volume } \\
\text { (L per plant) }\end{array}$} \\
\cline { 3 - 6 } & & V1 & V2 & V3 & V4 \\
\hline S. parahyba & 73 & 0.62 & 1.49 & 1.74 & 2.40 \\
C. myrianthum & 43 & 0.23 & 0.55 & 0.95 & 1.08 \\
C. speciosa & 52 & 0.40 & 0.52 & 0.66 & 0.85 \\
\hline
\end{tabular}

The volumes applied by irrigation did not generate percolation due to the association of SIC with the rain sensor. This fact contributed for the chemical analysis of the substrate, before (V0) and after (Phase I) the experimental period, for each treatment (V1 to V4), to indicate no statistical variation, at $5 \%$ significance level, for all elements studied, except for potassium (K), which decreased over time. The initial mean values of macronutrients, $\mathrm{N}(1.61 \%), \mathrm{P}(0.68 \%)$ and $\mathrm{K}(0.27 \%)$, and 
organic carbon $(9.66 \%)$, guaranteed the mineral supply, without the need for fertilization, especially in the initial stage of growth in tubes (Abreu et al., 2017).

At 80 days after emergency (DAE), when the seedlings were suitable for planting in the field, the small variation in the average macronutrient contents indicates that there was no restriction of these nutrients, ensuring growth with no limitations. The fact that there are no changes in the level of nutrients in the substrate indicates that, during the seedling production phase, there were enough nutrients to meet the demand of the species. It also indicates that part of the nutrients used by plants during the experimental period may have originated from the mineralization of biosolid organic matter.

The values of organic carbon (OC) were, on average, $9.7 \%$ at the beginning and $7.8 \%$ at the end of the experimental phase. Caldeira et al. (2013) state that the organic matter found in the substrates composed of biosolids, combined with the contents of nutrients, mainly $\mathrm{N}(1.61 \%$ at the beginning and $1.47 \%$ at the end of the experimental period $)$ and $\mathrm{P}(0.68 \%$ in both periods analyzed), are responsible for higher growth rates of forest seedlings. According to Guerrini and Trigueiro (2004), organic matter is a fundamental component of substrates, whose basic purpose is to increase the capacity of water and nutrient retention for seedlings and is directly related to organic carbon.

The efficiency of the biosolid in providing organic matter and nutrients is possibly related to the low carbon/nitrogen ratio (C/N) (Abreu et al., 2017). According to Gonçalves et al. (2000), materials with $\mathrm{C} / \mathrm{N}$ ratios greater than 18 usually have high activity of microorganisms, which start to compete with the seedlings for nutrients, mainly $\mathrm{N}$ and $\mathrm{S}(0.72 \%$ at the beginning and $0.78 \%$ at the end of the experimental period). In this study, the $\mathrm{C} / \mathrm{N}$ ratio was 5.95 before planting (V0) and 5.25, on average, for the treatments at the end of the nursery phase (80 DAE), indicating good conditions for plant growth.

The biosolid had adequate $\mathrm{pH}$ values, both at the beginning (5.3) and at the end of the experimental period (mean value of 5.1). This variable is important because it interferes in the availability of some micronutrients and may cause phytotoxicity to some plants. When organic substrates, without the addition of soil in the composition, are used, the recommendation is to work within a $\mathrm{pH}$ range from 4.4 to 6.2 (Kratz; Wendling, 2013). Ferraz, Centurion and Beutler (2005) recommend $\mathrm{pH}$ within the range from 5.2 to 5.5 for organic substrates.

In addition to fertility variables, seedling quality is associated with the physical characteristics of the substrate (Maeda et al., 2007). There was significant variation in volumetric density (Dv), particle density (Dp) and porosity $(\mathrm{P})$ in the substrate between the beginning (V0) and the end of the experimental phase (Table 2). Among the treatments (V1 to V4), at the end of the experimental period, there was variation only between Dv and Dp, which showed higher values in substrates that received higher flow rate. The increase in Dv from 0.4 (V0) to 0.56 (V1-2) and $0.62 \mathrm{~g} \mathrm{~cm}^{-3}$ (V3-4) was caused by the accommodation of particles over time. This accommodation led to a reduction of porosity $(\mathrm{P})$, which changed from $71.5 \%(\mathrm{~V} 0)$ to $65.91 \%(\mathrm{~V} 1-4)$.

According to Burés (1997), porous materials tend to settle over time, reducing porosity, which leads to permanent deformation. Among the treatments, the highest values of Dv and Dp are associated with higher irrigated volumes (V3 and V4), indicating a greater accommodation of particles and a possible more accelerated decomposition of organic matter, a component that can increase Dp values.

Table 2: Values of volumetric density (Dv), particle density (Dp) and porosity $(\mathrm{P})$ of the substrate at the beginning (V0) and at the end of the experimental period, for irrigation levels (V1 to V4).

\begin{tabular}{clll}
\hline Treatment & \multicolumn{1}{c}{$\mathrm{Dv}\left(\mathrm{g} \mathrm{cm}^{-3}\right)$} & $\mathrm{Dp}\left(\mathrm{g} \mathrm{cm}^{-3}\right)$ & $\mathrm{P}\left(\mathrm{cm}^{3} \mathrm{~cm}^{-3}\right)$ \\
\hline V0 & $0.40 \pm 0.04$ & $1.59 \pm 0.05$ & $0.747 \pm 0.02$ \\
V1 & $0.56 \pm 0.04 \mathrm{a}^{* * *}$ & $1.63 \pm 0.02 \mathrm{c}^{\mathrm{ns}}$ & $0.657 \pm 0.03 \mathrm{a} * * *$ \\
V2 & $0.56 \pm 0.07 \mathrm{a}^{* * *}$ & $1.66 \pm 0.02 \mathrm{c}^{*}$ & $0.661 \pm 0.04 \mathrm{a}^{* * *}$ \\
V3 & $0.62 \pm 0.02 \mathrm{a}^{* * *}$ & $1.72 \pm 0.06 \mathrm{~b}^{* * *}$ & $0.654 \pm 0.01 \mathrm{a}^{* * *}$ \\
V4 & $0.61 \pm 0.04 \mathrm{a}$ & $1.83 \pm 0.06 \mathrm{a}^{* * *}$ & $0.668 \pm 0.03 \mathrm{a}^{* * *}$ \\
\hline
\end{tabular}

Means followed in the column by the same letter do not differ from each other by Tukey test at $0.1 \%$ probability level. Means followed in the column by * $(5 \%)$ and *** $(0.1 \%)$ do not differ from Vo by Dunnett test. 
The aggregation of the substrate and the presence of living roots (Figure 1) make it possible to infer about the survival of the plant in the field and ease of handling at the time of planting (Moreira et al., 2016). In general, most seedlings received classification A or B; category B prevails for $S$. parahyba (Figure 1A) and C. speciosa (Figure 1C), while category A prevails for C. myrianthum (Figure 1B). For some plants, irrigation below the water need can stimulate root growth (Kang et al., 2016), as occurred for the V1 treatment of the species S. parahyba.

The substrate of treatment V3 for $S$. parahyba (Figure 1A) showed the best results, with $55.6 \%$ of classification A, $44.4 \%$ of classification $B$ and no classification $\mathrm{C}$, followed by $\mathrm{V} 2$, with $33.3 \%$ classification $\mathrm{A}$ and $66.7 \%$ of classification B. This result indicates that the highest (V4) and the lowest (V1) volumes applied to $S$. parahyba may have generated some interference in the root system growth. Although the results were similar, the factors that led the substrates of these treatments to receive a grade $\mathrm{C}$ were different, with a predominance of substrates that crumbled rapidly and had few roots in V1. For the substrates of the V4 treatment, classification $\mathrm{C}$ occurred mainly due to the low presence of apparent living roots. In these tubes there was better aggregation, but the small amount of living and apparent roots may have occurred because of death or because they received water in the absorption capacity, causing the plant not to invest in the expansion of the roots.

The substrates of the tubes with the species $C$. myrianthum (Figure 1B) obtained the best classification. Only the substrates of the treatment with lowest flow rate (V1) obtained a classification C (20\%). Classification A increased with the increase in flow rate, reaching $81.8 \%$ in the substrates of the treatments with highest flow rate (V4). It is verified that, for substrates with C. myrianthum, the increase in flow rate causes better root development and, consequently, better substrate aggregation.

For C. speciosa, there was no clear definition in the classification of substrates (Figure 1C), but it was possible to note an increase in classification A with the increase in flow rate, corresponding to $10.0,23.1,30.0$ and $36.4 \%$, respectively, for the substrates of the treatments V1 to V4. The lower volume of water required by the species (Table 1) may have negatively interfered in the aggregation and presence of living roots, besides the fact that some species have differentiated root growth over time, which will be verified with the analysis of dry mass in the next item.

$S$. parahyba, C. myrianthum and C. speciosa seedlings collected at $80 \mathrm{DAE}$ showed shoot height $(\mathrm{H})$ and collar diameter (D) according to the standards established by Davide et al. (2015) and Souza Junior and Brancalion (2016) (Figure 2). There was linear variation of height and collar diameter as a function of time, for the three species. After 15 days of the application of the treatments (35 DAE), the seedlings showed the first signs of differentiation in terms of growth (height and collar diameter), which became more visible from 50 DAE. In general, the growth is higher in treatments that received higher volumes of water (V3 and V4), while the V1 treatment had the lowest growth rate for all species.

Considering the regression equation and its identities, it is verified that for the species S. parahyba (Figures 2A and B), the average height $(30 \mathrm{~cm})$ and collar diameter $(5 \mathrm{~mm})$, considered standard, were reached at 60 and $68 \mathrm{DAE}$, for the treatments V4-V3 and V1-V2, in terms of height, respectively, and 32 and 34 DAE, for the treatments V1-V2-V3 and V4, in terms of collar diameter, respectively. These results are promising and show that all treatments were able to produce seedlings in a relatively short time interval.

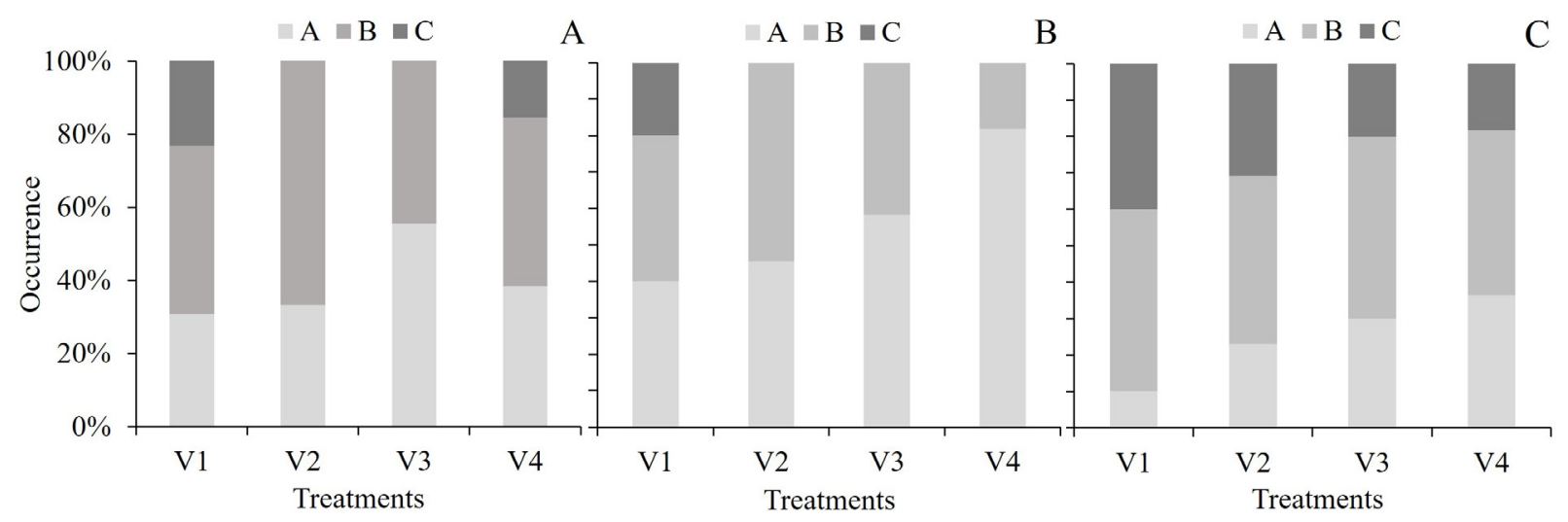

Figure 1: Evaluation of seedlings regarding substrate aggregation and presence of living roots in the species $S$. parahyba (A), C. myrianthum (B) and C. speciosa (C), for the irrigation levels (V1 to V4). 

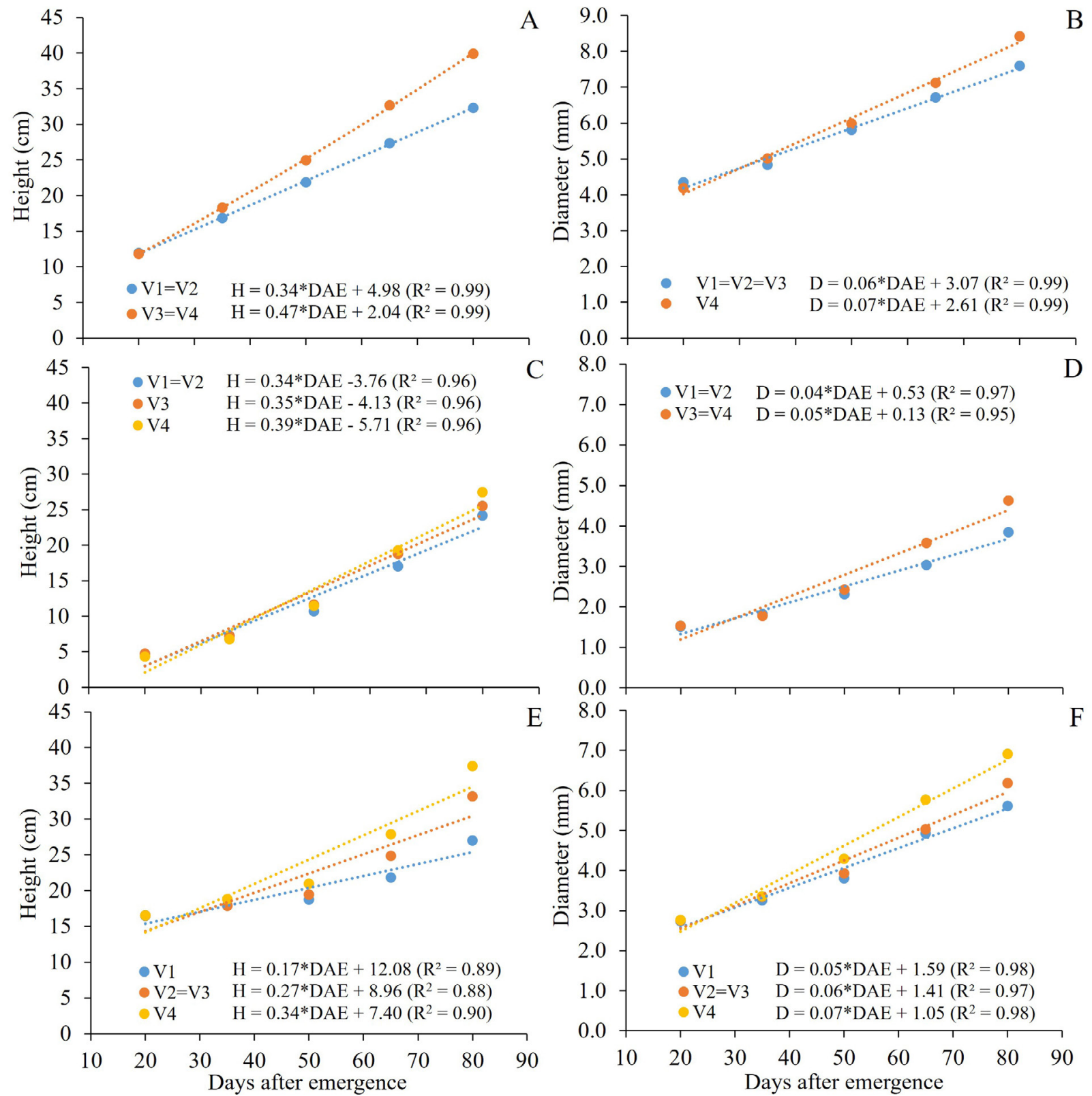

Figure 2: Growth in height and collar diameter, over the experimental period, of S. parahyba (A and B), C. myrianthum ( $\mathrm{C}$ and $\mathrm{D}$ ) and $\mathrm{C}$. speciosa ( $\mathrm{E}$ and $\mathrm{F}$ ) seedlings at the different irrigation levels (V1 to V4). * significant at $1 \%$ probability level by t-test.

Souza et al. (2003) recommend that $S$. parahyba seedlings be taken to the field with 25 to $30 \mathrm{~cm}$ of height and about 90 days after germination. If only this variable is considered, all irrigation levels would guarantee commercial standard of seedling production. However, other important characteristics should be considered for defining the quality standard of the seedlings. When studying the survival of seedlings in the field, Marques et al. (2006) found that tree species with the highest heights had lower rates of growth and survival after planting. Thus, it is necessary to analyze and compare the other quality factors of seedlings, such as dry mass accumulation, leaf area and chlorophyll content, so that their quality can be expressed more comprehensively. 
C. myrianthum seedlings (Figures $2 \mathrm{C}$ and $\mathrm{D}$ ) reached average standard values to be taken to the field $(25 \mathrm{~cm}$ height and $3 \mathrm{~mm}$ collar diameter) only at $79 \mathrm{DAE}$ in treatment $\mathrm{V} 4$, in terms of height, and at 61 (V1-V2) and 63 (V3-V4) $\mathrm{DAE}$, in terms of collar diameter. For the height variable, in the treatments V1-V2 and V3 the standard height would be reached at 85 and 83 DAE. These results indicate that the species $C$. myrianthum, under the production conditions of this study, showed gains of growth, in terms of collar diameter, but that for height a longer time would be required for the treatments V1 to V3 to reach the standards to be taken to the field. The V4 treatment had seedlings with better performance, but the other quality analyses will show if they have quality standards.

For C. speciosa seedlings (Figures $2 \mathrm{E}$ and $\mathrm{F}$ ), the commercial standards $(25 \mathrm{~cm}$ height and $5 \mathrm{~mm}$ collar diameter) were reached at 52,59 and $76 \mathrm{DAE}$, respectively, for the treatments V4, V2-V3 and V1, in terms of height, and at 56, 60 and $68 \mathrm{DAE}$, respectively, for the treatments $\mathrm{V} 4, \mathrm{~V} 2-\mathrm{V} 3$ and $\mathrm{V} 1$, in terms of collar diameter. These values indicate the good performance of C. speciosa under all levels of water supply, since Souza Junior and Brancalion (2016) consider the period from 90 to 120 days as necessary for the production of seedlings of native tree species, in 280 $\mathrm{cm}^{3}$ tubes. Under the studied conditions, it is verified that in terms of height and collar diameter, $S$. parahyba seedlings showed greater growth in shorter time, which may generate lower production costs for nursery managers.

The average leaf area (LA) for the three tree species varied linearly with the average total volume applied (accumulated volume per plant in each treatment), with greater response to the seedlings of $C$. speciosa (Figure 3). This species had the lowest average requirement per treatment (Table 1), indicating better water utilization. C. myrianthum seedlings showed an intermediate variation of LA between treatments, while $S$. parahyba seedlings showed the highest mean values of leaf area, but with the lowest variation as a function of the volume applied.

The highest values of total biomass (Figures 4A, B and C) are associated with the species $S$. parahyba. Among the treatments, for the three species studied, the highest values correspond to the highest volumes of water (V4). It is also verified that, in general, the seedlings from the treatments that received higher volumes of water of each species show higher values of shoot dry mass (SDM) compared to root dry mass (RDM). According to Schumacher, Ceconi and Santana (2004), SDM values higher than RDM indicate that there is an ideal supply of nutrients and adequacy of the species' growth to the substrate used.

On average, for S. parahyba plants (Figure 4A) there is increase of SDM and a visual decrease in the average $\mathrm{RDM}$ values in the tube phase, with the increase in the average volume accumulated per plant, indicating an adaptation of this species. Under conditions of ideal water supply (V4) or with supply close to ideal (V2 and V3), the plant invests in SDM, while under water restriction (V1), the plant tends to increase its mass of roots as a way to expand the absorption area. With less water, the ratio between SDM and RDM is lower, as this allows greater uptake and lower water loss.

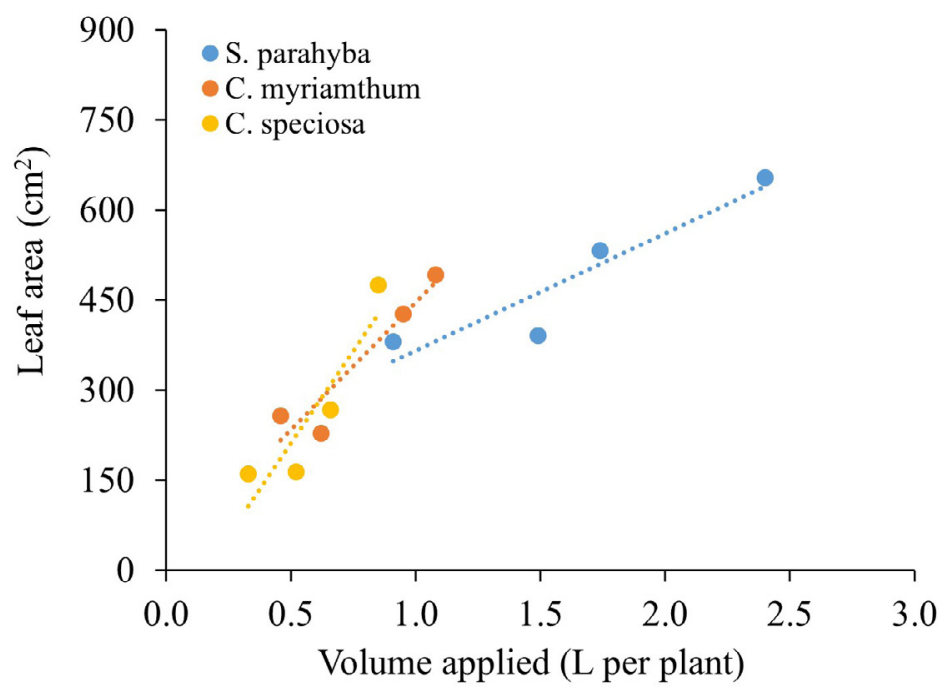

Figure 3: Variation of leaf area (LA) as a function of the total volume applied per plant (V) for at $5 \%$ probability level by t-test. 

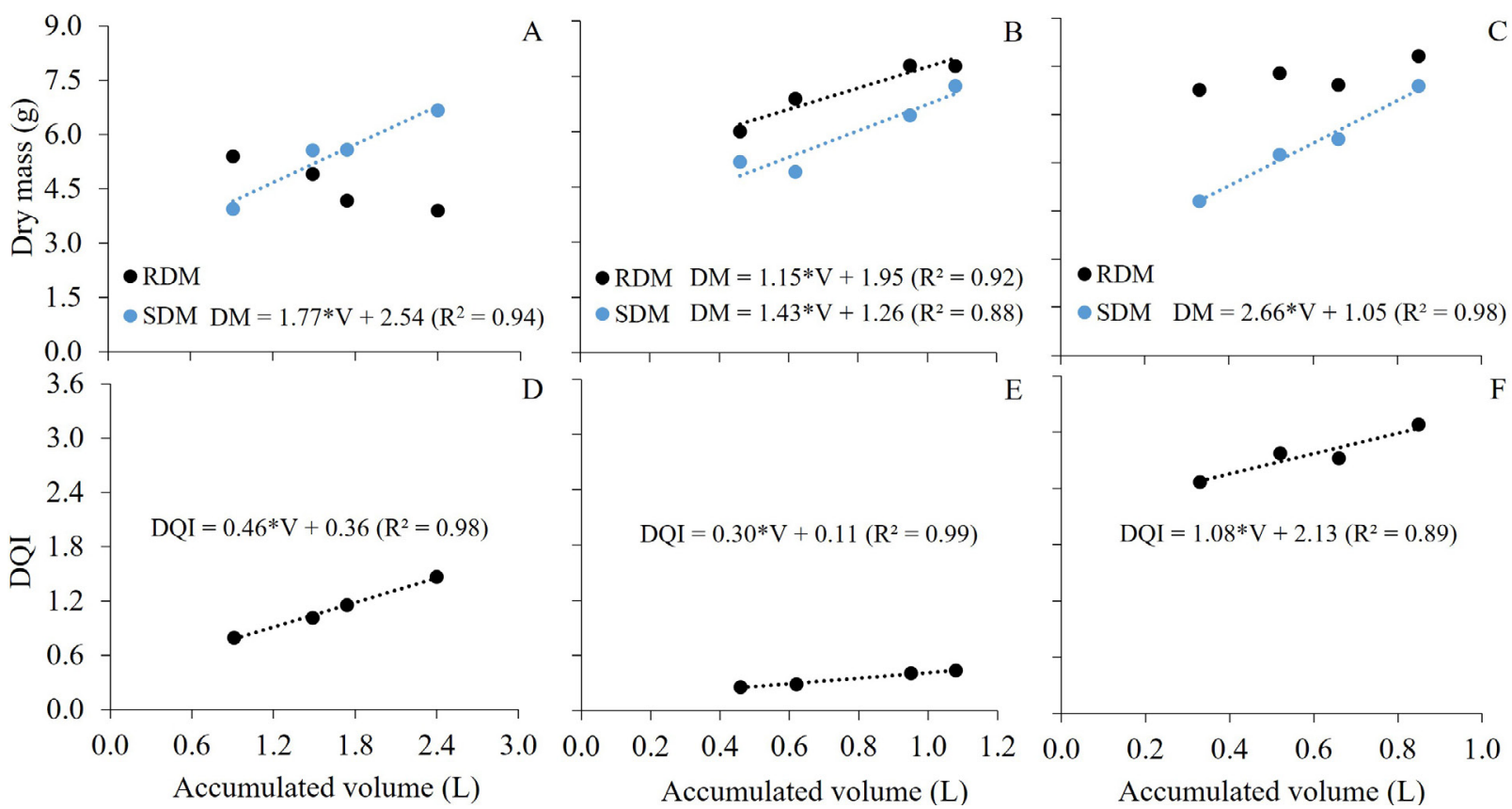

Figure 4: Mean values of dry mass ( $A, B$ and $C$ ) of the root system (RDM) and shoots (SDM), and Dickson quality index (DQI) (D, E and F), as a function of the volume of water applied per plant (V) for S. parahyba (A and D), $C$. myrianthum (B and E) and C. speciosa (C and F). * significant at 5\% probability levels by t-test.

The biomass of $C$. myrianthum (Figure 4B) shows a trend of increase for both SDM and RDM, as a function of the increase in the average volume accumulated per plant, in the tube phase. Andrade et al. (1999) state that seedlings of this species, produced under flood conditions, showed an increase in dry mass, root/shoot ratio, height, collar diameter and some morphological changes of the stem, such as hypertrophy of the collar. These results indicate that this species is more suitable for conditions with no water restriction since there is a significant increase in the TDM value in treatments V3 and V4.

C. speciosa seedlings (Figure 4C) showed similar values of RDM for all treatments in Phase I. For SDM, there was a trend of linear growth with the increase in the average accumulated volume per plant. For this species, there was greater differentiation between treatments in relation to SDM, as a function of the largest angular coefficient of the regression equation. This specificity can be considered as a greater adaptation of the species to the ideal condition of water supply when there is an increase in the shoots.

In general, the highest Dickson quality indices (DQI) (Figures 4D, E and F) are associated with seedlings that received higher water volume and showed accelerated growth (Figure 2). In this phase there is a linear response of DQI as a function of the irrigated volume of water, for the three species studied.

Chlorophyll $a$ content varied significantly as a function of the water volumes for the species $S$. parahyba (Figure 5A) and C. myrianthum (Figure 5C), while chlorophyll $b$ content varied significantly only for $S$. parahyba (Figure 5B). The observed trend is the decrease in chlorophyll contents with the increase in the volume of water applied. In general, this means that the chlorophyll content had little response to the applied water restriction and, in cases where there was variation, the lowest values seem to be related to an effect of dilution of pigments in tissues, due to the greater growth of seedlings that received higher volume of water (Figure 2).

The species $S$. parahyba showed the highest growth rate (Figures $2 \mathrm{~A}$ and $\mathrm{B}$ ) and biomass (Figures $5 \mathrm{~A}$ and $\mathrm{B}$ ). Together with the results of substrate aggregation (Figure 1), it is believed that at the end of the experimental phase of seedling production there was a certain equivalence between the evaluated treatments, which may be responsible for the reduction of chlorophyll contents.

Mild drought can cause increased chlorophyll content due to low leaf growth, while severe droughts 
can lead to chlorophyll degradation (Valença et al., 2018). This effect can be explained by the disproportionality or dilution of the $\mathrm{N}$ content (not measured) in the plants with greater growth, which corresponds to the treatments of higher irrigated volume. Booij, Valenzuela and Aguilera (2000) state that it is possible to relate the chlorophyll content with the nutritional status of the plant because the amount of this pigment correlates positively with $\mathrm{N}$ content in the plant. As there was little variation in chlorophyll $a$ and $b$ contents, it is assumed that the water restriction was not sufficient to cause chlorophyll degradation in plants that received lower volume of water and that, in plants with greater growth, which received higher volume, the lower values of chlorophyll $a$ and $\mathrm{b}$ are related to the dilution of chloroplasts caused by the accelerated growth.

For the initial growth period, when the same volume of water was applied to the previous treatments, chlorophyll levels did not vary according to these previous treatments.
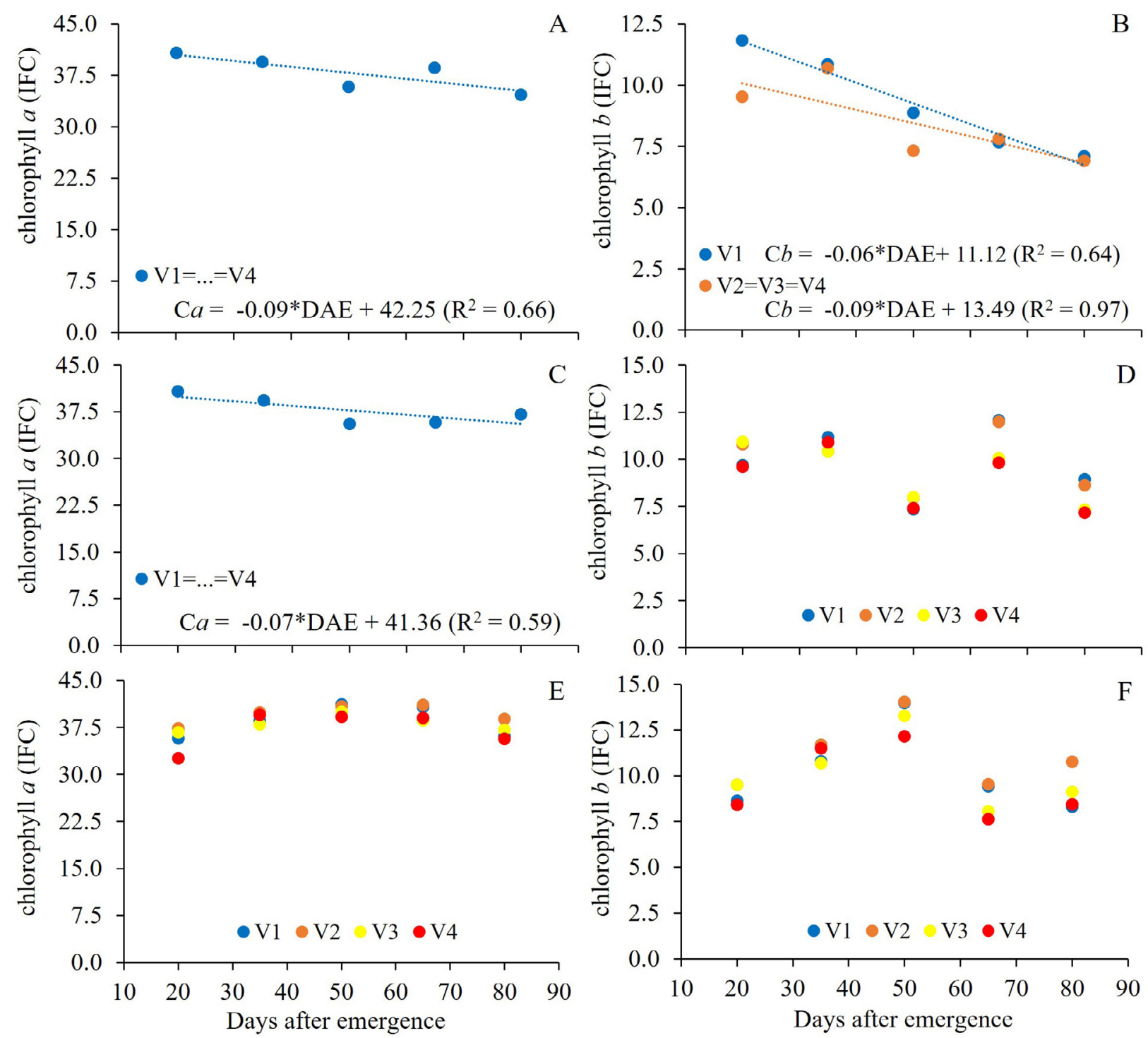

Figure 5: Variation of chlorophyll $a$ and $b$ contents during the seedling production period for tree species, Schizolobium parahyba (A and B), Cytharexyllum myrianthum ( $\mathrm{C}$ and D) and Ceiba speciosa (E and F). * significant at $5 \%$ probability level by t-test. 


\section{Simulation of initial growth (Phase II)}

The total volumes of water applied in the phase of initial growth of the plants under simulated field conditions were $70.0,50.3$ and $52.7 \mathrm{~L}$ per plant, respectively for $S$. parahyba, C. myrianthum and $C$. speciosa. The irrigation systems were actuated 97,88 and 94 times, respectively, for $S$. parahyba, C. myrianthum and C. speciosa. As occurred in Phase I, the largest volume and number of actuations are related to the species $S$. parahyba, which showed an average of 0.7 $\mathrm{L}$ per actuation, while $C$. myrianthum and $C$. speciosa showed averages of approximately $0.6 \mathrm{~L}$ per actuation.

The variables height and collar diameter for $S$. parahyba (Figure 6A), C. myrianthum (Figure 6B) and $C$. speciosa (Figure 6C) did not show significant differences between treatments PV1 to PV4, at $5 \%$ probability level by the t-test, in the first measurement after planting in a greenhouse (at 30 DAP). Thus, it is verified that, with only 30 days and without irrigation restriction, the plants reached the same level of growth, despite having been produced under levels of water restrictions.

For the three species studied, young plants had the same growth trend for both height and collar diameter, indicating rapid recovery of seedlings about 30 days after planting in pots. The angular coefficient of height lines as a function of time is higher for the species C. speciosa, followed by C. myrianthum and $S$. parahyba, while for collar diameter, the highest values were obtained for C. speciosa, followed by S. parahyba and $C$. myrianthum, whose values were similar. These results indicate a higher growth rate of $C$. speciosa in the initial growth phase.

The variation in height and collar diameter, verified between treatments at $80 \mathrm{DAE}$, became less evident at the end of the initial growth period, at 150 DAP (Table 3). In this last measurement, there was also no clear trend for biomass variables. At the end of the initial growth phase, there was no fit of regression for leaf area, as a function of the irrigation levels applied in the seedling production phase (PV1 To PV4). This result indicates that, for this variable, all species showed total recovery and good development when planted in pots and with water supply close to field capacity. However, when analyzing the aggregation of the substrate of the seedling production phase (Figure 1), it was verified that the seedlings subjected to water restrictions (treatments PV1 and PV2) did not show the same aggregation capacity, which can generate operational difficulties and losses in planting. These losses may generate interference in the final stand under actual conditions of planting in the field, where irrigation is rarely applied. Thus, it is suggested that a system with irrigation with a certain level of restriction, such as that applied in the treatment PV3, can promote better clod formation and, together with a higher ratio between root and shoot dry mass, is the most viable for the normal conditions of reforestation.
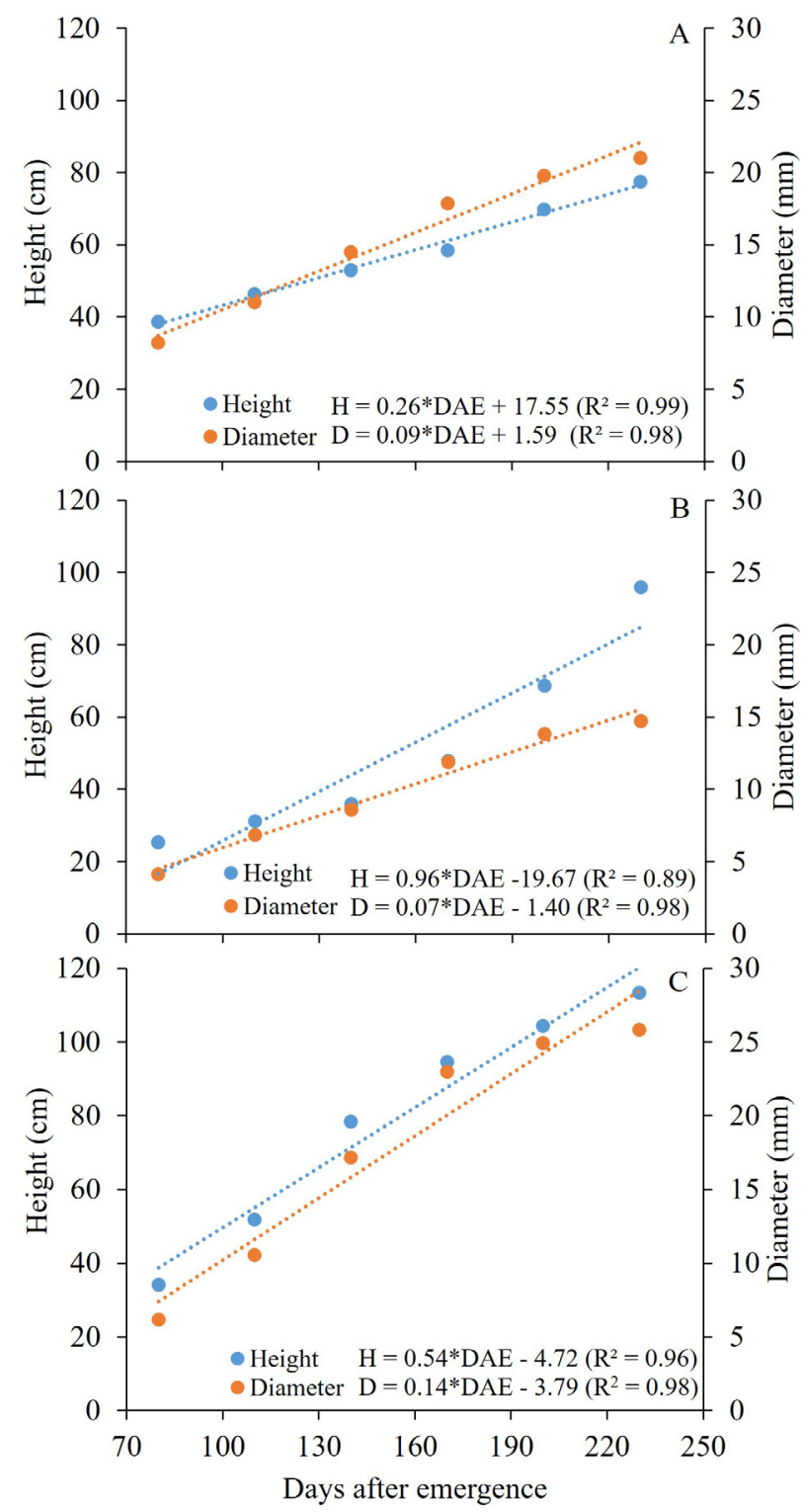

Figure 6: Variation of height and collar diameter over the experimental period in pots, for the species $S$. parahyba (A), C. myrianthum (B) and C. speciosa (C). * significant at $1 \%$ probability level by the t-test. 
Table 3: Values of height and collar diameter on the day of planting in pots (80 DAE), and biomass (shoot dry mass - SDM and root dry mass - RDM) per treatment (PV1 to PV4) at 150 days after planting (DAP)

\begin{tabular}{|c|c|c|c|c|c|c|c|}
\hline \multirow{2}{*}{$\mathrm{T}$} & \multirow{2}{*}{ Species } & \multicolumn{2}{|c|}{$\begin{array}{c}\text { Production of } \\
\text { seedlings - 80 DAE }\end{array}$} & \multicolumn{4}{|c|}{ Initial growth - 150 DAP } \\
\hline & & Height (cm) & Diameter (mm) & Height (cm) & Diameter $(\mathrm{mm})$ & SDM (g) & RDM (g) \\
\hline PV1 & \multirow{4}{*}{$\begin{array}{c}\text { S. } \\
\text { parahyba }\end{array}$} & $31.9 \pm 5.4 b$ & $6.9 \pm 0.8 b$ & $76.0 \pm 7.5 b$ & $21.0 \pm 1.8 \mathrm{a}$ & $117.6 \pm 15.3 \mathrm{ab}$ & $46.8 \pm 11.5 a$ \\
\hline PV2 & & $32.8 \pm 3,7 b$ & $7.7 \pm 0.7 a$ & $70.5 \pm 1.9 b$ & $21.2 \pm 0.8 \mathrm{a}$ & $82.9 \pm 23.5 b$ & $45.6 \pm 5.3 a$ \\
\hline PV3 & & $37.4 \pm 5.2 \mathrm{ab}$ & $8.1 \pm 0.7 a$ & $71.3 \pm 5.4 b$ & $20.3 \pm 0.9 a$ & $113.9 \pm 15.5 \mathrm{ab}$ & $47.3 \pm 7,5 \mathrm{a}$ \\
\hline PV4 & & $42.5 \pm 8.5 \mathrm{a}$ & $8.4 \pm 0.8 a$ & $91.8 \pm 10.7 a b$ & $21.6 \pm 0.4 a$ & $147.8 \pm 16.8 \mathrm{a}$ & $55.8 \pm 6.8 \mathrm{a}$ \\
\hline PV1 & \multirow{4}{*}{ myriamthum } & $23.9 \pm 1.9 a$ & $3.7 \pm 0.4 b$ & $89.3 \pm 10.5 a$ & $13.1 \pm 2.4 \mathrm{a}$ & $33.1 \pm 22.6 a$ & $43.9 \pm 20.6 a$ \\
\hline PV2 & & $24.4 \pm 5.5 a$ & $4.0 \pm 0.5 b$ & $102.3 \pm 7.2 \mathrm{a}$ & $15.3 \pm 1.6 \mathrm{a}$ & $57.0 \pm 15.3 \mathrm{a}$ & $68.2 \pm 29.2 a$ \\
\hline PV3 & & $25.5 \pm 4.0 \mathrm{a}$ & $4.6 \pm 0.4 a$ & $97.8 \pm 14.1 \mathrm{a}$ & $16.3 \pm 0.9 a$ & $59.5 \pm 6.4 \mathrm{a}$ & $89.1 \pm 9.5 \mathrm{a}$ \\
\hline PV4 & & $27.4 \pm 5.0 \mathrm{a}$ & $4.7 \pm 0.4 a$ & $94.5 \pm 11.5 \mathrm{a}$ & $14.2 \pm 0.7 a$ & $45.3 \pm 18.7 \mathrm{a}$ & $57.9 \pm 23.6 a$ \\
\hline PV1 & \multirow{4}{*}{$\begin{array}{c}\text { C. } \\
\text { speciosa }\end{array}$} & $27.0 \pm 3.7 c$ & $5.6 \pm 0.5 c$ & $109.0 \pm 4.8 \mathrm{a}$ & $24.9 \pm 2.7 a$ & $46.2 \pm 9.9 a$ & $62.7 \pm 29.5 a$ \\
\hline PV2 & & $31.5 \pm 5.9 \mathrm{cb}$ & $6.1 \pm 0.4 \mathrm{cb}$ & $109.3 \pm 3.3 a$ & $25.4 \pm 1.9 a$ & $58.1 \pm 6.9 a$ & $47.4 \pm 9.8 \mathrm{a}$ \\
\hline PV3 & & $34.9 \pm 4.9 \mathrm{ba}$ & $6.2 \pm 0.4 b$ & $112.0 \pm 8.6 a$ & $25.7 \pm 2.0 \mathrm{a}$ & $44.3 \pm 13.4 a$ & $60.1 \pm 9.3 a$ \\
\hline PV4 & & $37.4 \pm 6.2 \mathrm{a}$ & $6.9 \pm 1.0 \mathrm{a}$ & $123.5 \pm 9.3 a$ & $27.3 \pm 1.3 a$ & $51.2 \pm 11.2 \mathrm{a}$ & $66.8 \pm 8.2 \mathrm{a}$ \\
\hline
\end{tabular}

* For each species, means followed in the column by the same letter do not differ from each other by Tukey test, at $5 \%$ probability level.

\section{CONCLUSIONS}

The use of automatic irrigation and sewage sludge as substrate indicate that it is possible to save water and produce seedlings of forest species with quality, ensuring their survival in the field. Seedlings that receive less water than species' water requirement were able to recover on initial growth phase and reached the same size as the fully irrigated seedlings, when transplanted under adequate soil moisture conditions. Thus, we recommend the production of seedlings with irrigation levels slightly below the species requirement (1.74 L per plant - S. parahyba; $0.95 \mathrm{~L}$ per plant - $C$. myrianthum; and $0.66 \mathrm{~L}$ per plant - C. speciosa), which will generate savings in water use without loss of seedling quality.

\section{AUTHOR CONTRIBUTION}

Conceptual Idea: Carvalho, D.F.; Bueno, M.M.; Leles, P.S.S.; Methodology design: Carvalho, D.F.; Bueno, M.M.; Leles, P.S.S.; Data collection: Bueno, M.M.; Abreu, J.F.G.; Data analysis and interpretation: Carvalho, D.F.; Bueno; M.M., Leles, P.S.S., Medici, L.O.; Funding acquisition: Carvalho, D.F. and Writing and editing: Carvalho, D.F.; Bueno; M.M., Medici, L.O.

\section{ACKNOWLEDGMENTS}

This research was funded by Carlos Chagas Filho Foundation for Research Support of the State of Rio de Janeiro (FAPERJ) (grant E-26/202.909/2018), Brazilian National Council for Scientific and Technological Development (CNPq) (grant 310604/2018-4) and Coordination for the Improvement of Higher Level Personnel (CAPES) - Finance Code 001.

We thank the Federal Rural University of Rio de Janeiro, specifically the PPGA-CS, GPASSA and LAPER.

\section{REFERENCES}

ABREU, A. H. M. et al. Caracterização e potencial de substratos formulados com biossólido na produção de mudas de Schinus terebinthifolius Raddi. e Handroanthus heptaphyllus (Vell.) Mattos. Ciência Florestal, 27(4):1179-1190, 2017.

ALVES JÚNIOR, J. et al. African mahogany submitted to drip irrigation and fertilization. Revista Árvore, 41(1):e410112, 2017.

ANDRADE, A. C. S. D. et al. Flooding effects in seedlings of Cytharexyllum myrianthum Cham. and Genipa americana L.: Responses of two neotropical lowland tree species. Brazilian Journal of Botany, 22:281-285, 1999. 
ANJUM, S. et al. Morphological, physiological and biochemical responses of plants to drought stress. African Journal of Agricultural Research, 6(9):2026-2032, 2011.

BOLUWADE, A.; MADRAMOOTOO, C. A. Independent principal component analysis for simulation of soil water content and bulk density in a Canadian Watershed. International Soil and Water Conservation Research, 4(3):151-158, 2016.

BOOIJ, R.; VALENZUELA, J. L.; AGUILERA, C. Determination of crop nitrogen status using non-invasive methods. In: HAVERKORT, A. J.; MACKERRON, D. K. L. (Eds.). Management of nitrogen and water in potato production. The Netherlands, Wageningen Pers, p.72-82, 2000.

BUENO, M. M. et al. Water use in the growth of seedlings of Atlantic Forest tree species under different shading levels. Ciencia e Agrotecnologia, 45:e025220, 2021.

BURÉS, S. Sustratos. Madrid: Ediciones agrotécnicas. 1997.341p.

CALDEIRA, M. V. W. et al. Substratos alternativos na produção de mudas de Chamaecrista desvauxii. Revista Árvore, 37(1):31-39, 2013.

CRUZ, E. et al. Growth of black pepper plantlets under different substrates and irrigation levels. Scientia Agricola, 79:e20200094, 2022.

DAVIDE, A. C. et al. Fatores que afetam a qualidade de mudas destinadas aos projetos de restauração de ecossistemas florestais. In: DAVIDE, A. C.; BOTELHO, S. A. (Eds.). Fundamentos e métodos de restauração de ecossistemas florestais: 25 anos de experiência em matas ciliares. Lavras: UFLA, p.181-274, 2015.

DICKSON, A.; LEAF, A. L.; HOSNER, J. F. Quality appraisal of white spruce and white pine seedling stock in nurseries. Forest Chronologe, 36:10-13, 1960.

DUMROESE, R. K. et al. Exponential fertilization of pinus monticola seedlings: Nutrient uptake efficiency, leaching fractions, and early outplanting performance. Canadian Journal of Forest Research, 35(12):89-97, 2005.

FERMINO, M. H. Substratos: Composição, caracterização e métodos de análise. Guaíba: Agrolivros, 2014.111p.

FERRAZ, M. V.; CENTURION, J. F.; BEUTLER, A. N. Caracterização física e química de alguns substratos comerciais. Acta Scientiarum. Agronomy, 27(2):209-214, 2005.

GOMES, D. P. et al. Growth and production of tomato fertilized with ash and castor cake and under water depths, cultivated in organic potponics. Acta Scientiarum. Agronomy, 39(2):201-209, 2017.
GOMES, J. M. et al. Parâmetros morfológicos na avaliação de qualidade de mudas de Eucalyptus grandis. Revista Árvore, 26(6):655-664, 2002.

GONÇALVES, J. L. M. et al. Aplicabilidade de lodo de esgoto em plantações florestais: 2- efeito na fertilidade do solo, nutrição e crescimento das árvores. In: BETTIOL, W.; CAMARGO, O. A. (Eds.). Impacto ambiental do uso agrícola do lodo de esgoto. Jaguariúna: EMBRAPA Meio Ambiente, p. 179-195, 2000.

GRAYBILL, F. A. Theory and application of the linear model. Belmont: Duxbury. 2000. 704p.

GUERRINI, I. A.; TRIGUEIRO, R. M. Atributos físicos e químicos de substratos compostos por biossólidos e casca de arroz carbonizada. Revista Brasileira de Ciências do Solo, 28(6):1069-1076, 2004.

KANG, S. et al. Improving agricultural water productivity to ensure food security in China under changing environment: From research to practice. Agricultural Water Management, 179:5-17, 2017.

KEFFER, J. F. et al. Evapotranspiration and water sensitivity of Amazonian yellow ipe seedlings under different shading conditions. Revista Brasileira de Engenharia Agrícola e Ambiental, 23(10):733-740, 2019.

KRATZ, D.; WENDLING, I. Produção de mudas de Eucalyptus dunnii em substratos renováveis. Revista Floresta, 43(1):125-136, 2013.

LAAKKONEN, A.; HUJALA, T.; PYKÄLÄINEN, J. Integrating intangible resources enables creating new types of forest services - developing forest leasing value network in Finland. Forest Policy and Economics, 99:157-168, 2018.

LIMA FILHO, P. et al. Produção de mudas de Ceiba speciosa em diferentes volumes de tubetes utilizando o biossólido como substrato. Ciência Florestal, 29(1):27-39, 2019.

MAEDA, S. et al. Caracterização de substratos para produção de mudas de espécies florestais elaborados a parir de resíduos orgânicos. Pesquisa Florestal Brasileira, 54:97104, 2007.

MANTRI, N. et al. Abiotic stress responses in plants: present and future. In: AHMAD, P.; PRASAD, M. N. V. (Ed.). Abiotic stress responses in plants: Metabolism, productivity and sustainability. New York: Springer, p. 1-19, 2012.

MARQUES, V. B. et al. Efeito de fontes e doses de nitrogênio sobre o crescimento inicial e qualidade de mudas de jacarandá-da-bahia (Dalbergia nigra (Vell.) Fr. All. ex Benth.). Revista Árvore, 30(5):725-735, 2006. 
MEDICl, L. O. et al. Automatic controller to water plants. Scientia Agricola, 67(6):727-730, 2010.

MELLO, G. A. B. et al. Organic cultivation of onion under castor cake fertilization and irrigation depths. Acta Scientiarum -Agronomy, 40:e34993, 2018.

MOREIRA, G. G. et al. A qualidade de mudas clonais de Eucalyptus urophylla $\times$ E. grandis impacta o aproveitamento final de mudas, a sobrevivência e o crescimento inicial. Série Técnica-Instituto de Pesquisas e Estudos Florestais, 24(45):33-37, 2016.

OLIVEIRA, A. B.; MENDES, N. L.; GOMES FILHO, E. Comparison between the water and salt stress efects on plant growth and development. In: $\mathrm{AKINCI}, \mathrm{S}$. (ed.). Responses of organisms to water stress. London: IntechOpen p. 70-94, 2013.

PERTASSEK, T.; PETERS, A.; DURNER, W. HYPROP-FIT Software user's manual, V. 3.0. UMS GmbH, München, Germany, 2015, 66p. Available in: <http://www.soil.tu-bs.de>. Access in: August, 01, 2020.

SABONARO, D. Z.; GALBIATTI, J. A. Efeito de níveis de irrigação em substratos para a produção de mudas de ipê-roxo. Scientia Forestalis, (74):95-102, 2007.

SCHINDLER, U.; MÜLLER, L. Simplifying the evaporation method for quantifying soil hydraulic properties. Journal of Plant Nutrition and Soil Science, 169(5):623-629, 2006.
SCHUMACHER, M. V.; CECONI, D. E.; SANTANA, C. A. Influência de diferentes doses de fósforo no crescimento de mudas de angico vermelho (Parapiptadenia rígida (Bentham). Brenan). Revista Árvore, 28(1):149-155, 2004.

SILVA, O. M. C. et al. Potencial uso da casca de café como constituinte de substrato para produção de mudas de espécies florestais. Ciência Florestal, 30(4):1161-1175, 2020.

SIQUEIRA, D. P et al. Lodo de esgoto tratado na composição de substrato para produção de mudas de Plathymenia reticulata Benth. Ciência florestal, 29(2):728-739, 2019.

SOUZA JÚNIOR, C. N.; BRANCALION, P. H. S. Sementes e mudas: guia para propagação de árvores brasileiras. Oficina de textos, São Paulo, 2016. 463p.

SOUZA, C. R. et al. Paricá: Schizolobium parahyba var. amazonicum (Huber x Ducke) Barneby. Embrapa Amazônia Ocidental-Circular Técnica (INFOTECA-E), 2003. 12p.

TEIXEIRA, P. C. et al. Manual de métodos de análise de solo. Rio de Janeiro, Embrapa. 2017. 573p.

VALENÇA, D.C. et al. Automatically controlled deficit irrigation of lettuce in organic potponics. Scientia Agricola, 75(1):5259, 2018.

ZOGHLAMI, R. I. et al. Monitoring the variation of soil quality with sewage sludge application rates in absence of rhizosphere effect. International Soil and Water Conservation Research, 8(3):245-252, 2020. 